\title{
Is male condition corrected with song features in Dusky Warblers (Phylloscopus fuscatus)
}

Jiaojiao Wang ${ }^{1,2}$, Jianping Liu², Zhenqun Zhang ${ }^{1}$, Hongxin Ren ${ }^{1}$, Lijie Gao ${ }^{3}$ and Jianhua Hou ${ }^{1 *}$ (D)

\begin{abstract}
Background: Birdsong is an important form of communication that plays an important role in territorial defense and mate attraction by conveying valuable information. While body-size and song frequency are often negatively correlated among species, this relationship is only found in a few songbirds. Previous studies on the Dusky Warbler (Phylloscopus fuscatus) found that there was a positive correlation between tarsus length and peak frequency. And heavier male Dusky Warblers possess better territories and obtain more opportunities for mating; body condition may be related to reproduction of birds, so females may choose heavier mates or better body condition based on the singing characteristics of males.
\end{abstract}

Methods: We recorded spontaneous song and measured morphology of 33 male Dusky Warblers in Saihanba Forest Farm area between July 5 and August 10,2015. We chose body weight as an indicator of body size and defined body condition as residuals from a linear regression between body weight and tarsus length. Frist, we used Pearson correlation to analyze whether date and time of day were correlated with weight, and then we used linear regression to analyze whether sound features could indicate the body weight and body condition. We call body weight and body condition the male condition.

Results: We found no effect of date and time of day on weight, and we showed a correlation between the male condition and song features in the small songbird, Dusky Warbler. Maximum trill quality and maximum peak frequency of songs were negatively related to male condition; the mean number of syllables of songs and maximum high frequency of songs were positively correlated with body weight and body condition.

Conclusions: In the small songbird, Dusky Warbler, four song parameters, including maximum trill quality, mean number of syllables of songs, maximum peak frequency of songs, maximum high frequency of songs, significantly predicted male condition change of which the most important song characteristic for male condition was maximum trill quality. This study suggested that the extreme song features were more constrained by male condition than mean sound characteristics.

Keywords: Bird song, Dusky Warbler, Male condition, Male weight, Song characteristics

\footnotetext{
*Correspondence: 2056264658@qq.com

${ }^{1}$ College of Life Science, Hebei University, 54 East Road, Baoding 071000,

China

Full list of author information is available at the end of the article
} 


\section{Background}

In birds, body size plays an important role in numerous aspects of their life (Hall et al. 2013), including territorial competition and mate choice, in which mutual assessment of body size between individuals can be valuable (Cardoso et al. 2008). Research has shown that in some birds, females select males according to male song (Forstmeier et al. 2002; Byers 2007). Males in prime condition have higher survival, thus such males may also be better able to provide resources, parental care, or optimal genes (Candolin and Voigt 2001; Byers et al. 2016). Additionally, males may adjust their behavior according to different song opponents (Jonart et al. 2007).

Birdsong plays an important role in bird communication, although it is not always reliable (Kroodsma and Byers 1991; Catchpole and Slater 2008). The production of bird song is constrained by the size of the syrinx or length of the trachea (Wallschläger 1980). Vocal organs positively correlate with body size in many animal species, and, therefore, large animals with larger vocal organs produce lower frequency signals than smaller ones (Cardoso et al. 2008; Hall et al. 2013), which may signal body size to other individuals, such as used in mate choice or territorial competition (Handford and Lougheed 1991; Gil and Gahr 2002; Irwin et al. 2008; Brumm 2009; Price and Christopher 2013). Since 1980, ornithologists have reported that there is a negative relationship between sound character and body size across species of birds (Wallschläger 1980; Tubaro and Mahler 1998; Bertelli and Tubaro 2002; Martin et al. 2011). Recently, this relationship has been demonstrated within a single species as well, including various insects, birds, and mammals (Davies and Halliday 1978; Cardoso 2012; Linhart et al. 2012; Linhart and Fuchs 2015). However, this relationship is inconsistent in some species (Galeotti et al. 1997; Patel et al. 2010; Potvin 2013; Linhart and Fuchs 2015; Miyashita et al. 2016; Liu et al. 2017). This raises questions about the underlying mechanisms. Body condition involves many things and is often seen as a measure of energy stores (primarily fat), which is related to the survival, behavior and reproduction of birds. There are many indicators used to represent body conditions, such as fat scoring, residual condition indicators, or ratio, etc. (Labocha and Hayes 2012).

A problematic feature of birdsong is that it consists of a cluster of characters, rather than a simple feature, each of which may be constrained by specific constraints (Gil and Gahr 2002; Catchpole and Slater 2008). Receivers may gain information from signalers not only through the full song by means of repertoire size, but also through subtle variation in the sound (such as trill performance). Studies have shown that females prefer males with high performance trill (song approaching performance limits, which has a wider bandwidth and a faster trill rate) (Draganoiu et al. 2002; Ballentine et al. 2004; Botero et al. 2009).

The Dusky Warbler (Passeriformes, Sylviidae) is a socially polygynous, long-distance migratory passerine. Its song has many functions, mainly territorial defense and mate attraction (Forstmeier and Balsby 2002; Zheng 2011). Dusky Warblers have two song types, S-song and $\mathrm{V}$-song: the function of S-song is territory defense, while $\mathrm{V}$-song is used for advertising male quality (Forstmeier and Balsby 2002). Male Dusky Warblers sing before and after pairing to ensure within-pair paternity and acquisition of extra-pair copulations (Forstmeier and Balsby 2002). Peak song frequency is positively related to tarsus length, suggesting that peak frequency is a reliable indicator of tarsus length (Liu et al. 2017). Dusky Warblers defend their territory throughout the breeding season, while other passerines give up their territory during the post-nuptial moulting period (Forstmeier 2002). Body weight is positively correlated with pairing success, and, in addition, females choose their mates based on the quality of the song, not the quantity (Forstmeier 2002). Most Dusky Warbler songs contain a trill, in which the bandwidth is negatively correlated with the trill rate (Ivanitskii et al. 2012; Liu et al. 2016). Thus it is difficult to produce high quality trills. However, it remains unknown whether morphological parameter is correlated with song characteristics.

In this study, we chose body weight as an indicator of body size and defined body condition as residuals from a linear regression between body weight and tarsus length, with positive residuals reflecting better body condition, then we analyzed the relationship between characteristics of the song and male weight or body condition. Because biologists also use weight as the simplest condition indicator (Labocha and Hayes 2012), for the convenience of expression, we used male condition instead of body weight and body condition (Galeotti et al. 1997).

\section{Methods \\ Study site and population}

We conducted our investigation using a population of male Dusky Warblers in Saihanba Forest Farm, Hebei Province, China $\left(42^{\circ} 02^{\prime}-42^{\circ} 36^{\prime} \mathrm{N}, 116^{\circ} 51^{\prime}-117^{\circ} 39^{\prime} \mathrm{E}\right)$. This region is classified as belonging to a cold temperate zone with a continental monsoon climate. The field work was conducted from July 5 to August 10, 2015.

Dusky Warblers are seasonally resident along the banks of the Malkachan River from the end of May to early September (Forstmeier and Balsby 2002). During breeding, male birds do not guard fertile females, but do sing more often when their partners are fertile (Forstmeier et al. 2002). Dusky Warblers defend their territory throughout the breeding season (Forstmeier 2002). 


\section{Sound recording and measurements}

We recorded 33 male Dusky Warblers between July 5 and August 10, 2015 during the breeding season. All recordings were made during fine weather (e.g., no wind or rain) between 5:00 and 10:00 a.m. We used a TASCAM DR-680 recorder (Tascam, DR-600, Japan), put power module (pinsheng, TS-MC006, China) in it, connected to a Sennheiser ME67 microphone (ME67, Sennheiser Electronic, Germany) to record the songs, with a sampling rate of $44.1 \mathrm{kHz}$ and a 16-bit depth. Each recording was made for about $10 \mathrm{~min}$ while maintaining the recording distance as close to $10 \mathrm{~m}$ as possible. After recording, birds were captured in a mist net by attracting them using playback via a SONY SRS-XB2 Bluetooth (SONY, SRS-XB2, Japan) loudspeaker. A G\&G TS300 electronic balance (G\&G, TS300, USA) was used to weigh birds to within $0.01 \mathrm{~g}$. Tarsus length was measured with an electronic digital indicator (Kafuweier, YB5001B, China) within $0.01 \mathrm{~mm}$. All measurements were performed by the same researcher. There were several reasons why we chose weight as an indicator of body size: (1) heavier males are more likely to be polygamous, and females may choose mates through the male's song (Forstmeier 2002), (2) in small songbird species, strong evidence of a link between body weight and sound characteristics is lacking (Cardoso et al. 2008; Lu et al. 2014; Linhart and Fuchs 2015). Males were released in good condition within $5 \mathrm{~min}$ of capture. Capture locations were recorded using a Jisibao R600GPS (Jisibao, R600, China).

Sonograms were generated using Raven Pro sound analysis software (version 1.4; Cornell Laboratory of Ornithology, Ithaca, NY), with a Hann spectrogram window, DFT size of 512 samples, hop size of $3.4 \mathrm{~ms}$, sampling frequency of $44.1 \mathrm{kHz}$, and time resolution of $11.6 \mathrm{~ms}$. As in previous research on Dusky Warblers, we only analyzed the V-song type (Liu et al. 2017) (Fig. 1). We used the cross shape on the software to draw the rectangle which wrapped spectrogram of songs around it, followed by selecting the following parameters, namely low frequency, high frequency, center frequency, bandwidth, peak frequency, the number of syllables and duration of songs and trill, start frequency and end frequency of songs, and in addition, we calculated the trill rate and trill quality (trill rate * bandwidth) (Liu et al. 2017). We visually measured the number of syllables in a song or trill according to the sound spectrogram (Fig. 1).

Referring to Raven's manual and relevant studies (Wallschläger 1980; Martens et al. 2004; Päckert et al. 2005; Xiao et al. 2008; Labocha and Hayes 2012; Liu 2016), the following terms of song and body condition are used in this paper (some of the sound parameters are shown in Fig. 1):

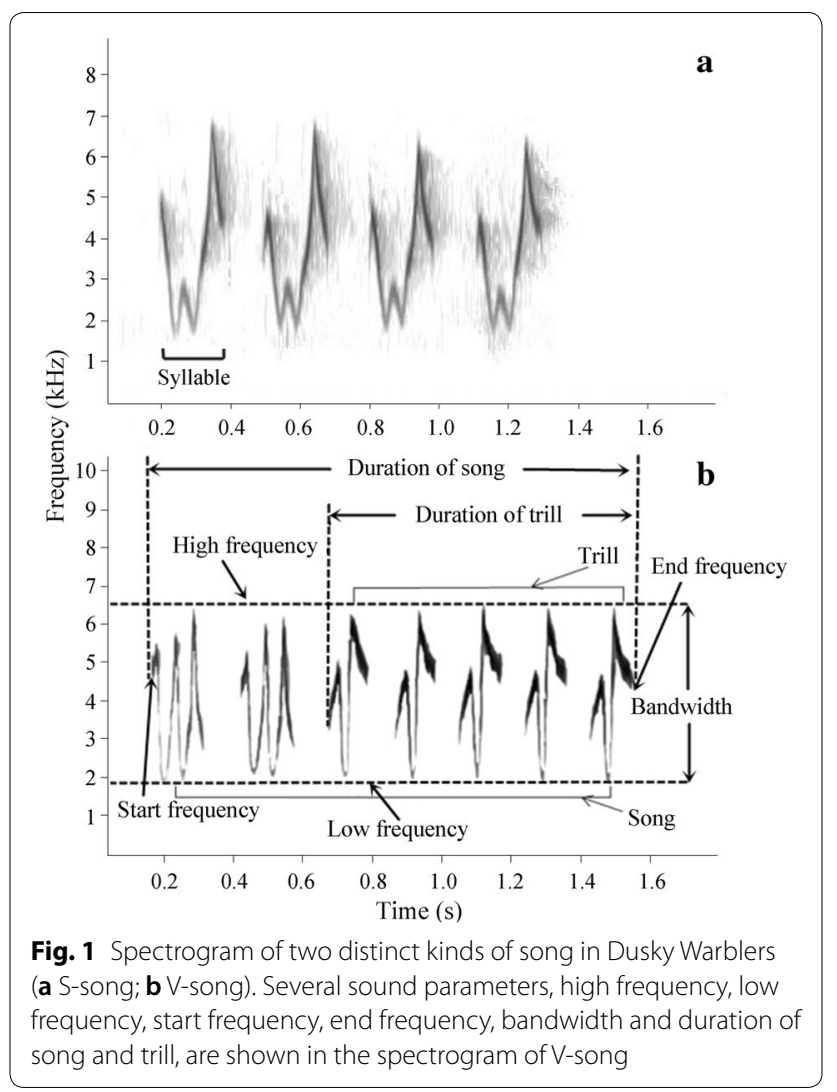

Song: the long, complex sound produced by males during the breeding season, a continuous segment containing notes or syllables, usually separated by a blank pause.

Trill: a continuous structure produced by the repetition of several identical syllables.

Peak frequency: frequency at which maximum power is reached.

Center frequency: the frequency at which the energy is equal.

Trill rate: the number of notes or syllables per second in a trill.

Trill quality: the product of trill rate and bandwidth. Body condition: it involves many things and is often seen as a measure of energy stores (primarily fat).

We measured on average $42.24 \pm 15.72$ songs and $20.36 \pm 9.17$ (mean \pm SD) trills for each male. Therefore, we calculated the average of each parameter for each male. We also chose the absolute minimum and maximum of each parameter for each male, because the limits 
of song features may be physiologically limited (Linhart and Fuchs 2015; Liu et al. 2017).

\section{Statistical analyses}

We eliminated the effects of date and time of day on body weight by subtracting dates from the first day of the experiment $($ mean $=27.64, \mathrm{SD}=5.493)$, and time of day was defined as the number of minutes after sunrise (mean $=120.18, \mathrm{SD}=70.072$ ) (Galeotti et al. 1997; Linhart et al. 2012). We used Pearson correlation to analyze whether date and time of day were correlated with weight. Some studies have used tarsus length corrected for weight (Galeotti et al. 1997; Jones et al. 2017), and we also did this. We used the linear regression residuals of tarsus length and body weight as the condition, with positive residuals reflecting better body condition (Jones et al. 2017), although previous studies did not find any effect on weight by other parameters (Liu 2016). Residuals in the regression model were normally distributed. We used the linear regression to analyze whether there were sound parameters that were able to predict weight or condition. All statistical analyses were conducted using IBM SPSS Statistics 22.0.

\section{Results}

Song parameters and male condition

Average weight of 33 Dusky Warblers for which songs were recorded was $10.04 \pm 0.47 \mathrm{~g}$ (mean $\pm \mathrm{SD}$ ). Descriptive statistics of song parameters are shown in Additional file 1: Table S1. There was no significant correlation between the two environmental factors, date and time of day, and weight $\left(r_{1}=0.066, p_{1}=0.716\right.$; $\left.r_{2}=0.036, p_{2}=0.841\right)$. The results of the linear regression model showed that four song parameters can significantly predict weight. Maximum trill quality which was the most important parameter was negatively correlated with weight $(t=-4.466, p<0.001)$; the mean number of syllables of songs was positively correlated with weight $(t=3.502, p=0.002)$; maximum peak frequency of songs was negatively related to body weight $(t=-3.085, p=0.005)$; maximum high frequency of songs was positively related to body weight $(t=2.361$, $p=0.025$ ) (Table 1).

The same results were obtained when the relationship between body condition and sound parameters was analyzed: the maximum trill quality which was the most important parameter was negatively correlated with condition $(t=-4.259, p<0.001)$; the average

Table 1 Analysis of the relationship of weight and sound parameters using linear logistic regression

\begin{tabular}{|c|c|c|c|c|c|}
\hline \multirow[t]{2}{*}{ Parameters } & \multirow{2}{*}{$\begin{array}{l}\text { Standardized } \\
\text { coefficients beta }\end{array}$} & \multirow[t]{2}{*}{$t$} & \multirow[t]{2}{*}{$p$} & \multicolumn{2}{|c|}{$95.0 \%$ confidence interval for B } \\
\hline & & & & Lower bound & Upper bound \\
\hline Constant & & 6.688 & 0.000 & 6.879 & 12.953 \\
\hline Maximum trill quality & -0.819 & -4.466 & 0.000 & 0.000 & 0.000 \\
\hline Mean number of syllables of songs & 0.621 & 3.502 & 0.000 & 0.140 & 0.535 \\
\hline Maximum peak frequency of songs & -0.392 & -3.710 & 0.001 & -0.001 & 0.000 \\
\hline Maximum high frequency of songs & 0.397 & 3.759 & 0.001 & 0.000 & 0.001 \\
\hline Dependent variable: body mass & & & & & \\
\hline
\end{tabular}

Sound parameters that entered the model were significantly correlated with weight

Table 2 Analysis of the relationship between condition and sound parameters using linear logistic regression

\begin{tabular}{|c|c|c|c|c|c|}
\hline \multirow[t]{2}{*}{ Parameters } & \multirow{2}{*}{$\begin{array}{l}\text { Standardized } \\
\text { coefficients beta }\end{array}$} & \multirow[t]{2}{*}{$t$} & \multirow[t]{2}{*}{$p$} & \multicolumn{2}{|c|}{$95.0 \%$ confidence interval for $B$} \\
\hline & & & & Lower bound & Upper bound \\
\hline Constant & & -0.080 & 0.937 & -6.597 & 6.104 \\
\hline Maximum trill quality & -0.790 & -4.259 & 0.000 & 0.000 & 0.000 \\
\hline Mean number of syllables of songs & 0.612 & 3.440 & 0.002 & 0.280 & 1.106 \\
\hline Maximum peak frequency of songs & -0.421 & -3.296 & 0.003 & -0.002 & 0.000 \\
\hline Maximum high frequency of songs & 0.413 & 2.492 & 0.019 & 0.000 & 0.001 \\
\hline Dependent variable: condition & & & & & \\
\hline
\end{tabular}


number of syllables of songs was positively correlated with condition $(t=3.400, p=0.002)$; maximum peak frequency of songs was negatively related to body condition ( $t=-3.296, p=0.003)$; maximum high frequency of songs was positively related to body condition $(t=2.492, p=0.019)$ (Table 2).

\section{Discussion}

Four song parameters significantly predicted male condition, including maximum trill quality, average number of syllables of songs, maximum peak frequency of songs, maximum frequency of songs, and the results suggested that except for the number of syllables, the extreme song features were more constrained by male condition than mean sound characteristics. This study showed that Dusky Warblers may use the extreme song features as a signal of sexual selection.

Song consists of a cluster of characters, each of which may be subject to specific constraints (Gil and Gahr 2002; Catchpole and Slater 2008). Previous study about Dusky Warblers has shown that there are 205 types of syllables in their song (Forstmeier and Balsby 2002). In birds that produce songs with large repertoires, they may choose features that are readily available for judging individuals, to avoid the cost of long listening sessions (Botero et al. 2009). Therefore, Dusky Warblers may use different song features to encode information about weight or condition rather than song types.

Song plays an important role in mate selection and territorial competition (Catchpole and Slater 2008). Female Dusky Warblers prefer heavier males (Forstmeier 2002). Body condition was also related to the reproduction of birds (Labocha and Hayes 2012). Females may choose males with better body condition through sound, and females mating with such males may obtain direct or indirect benefits. In territorial competition, the battle of physical contact is costly, so birds can use sound signals to modulate aggressive interactions (Davies and Halliday 1978; Robertson 1986; Wagner 1989; Hughes 1996; Searcy et al. 2006; Hardouin et al. 2007; Linhart et al. 2012; Linhart and Fuchs 2015). Previous study suggested that heavy male Dusky Warblers were more likely to win in territorial competition (Forstmeier 2002), indicating they judge each other based on sound characteristics (Linhart et al. 2012; Linhart and Fuchs 2015). This study has shown the relationship between song features and male condition, which provides evidence for the research on the relationship between body size or condition and sound parameters in small songbirds.

Some studies indicate that birds lose weight when they reach the breeding grounds (Galeotti et al. 1997). We did experiments at the female incubation period, collecting data over a short period of time. However, we found no significant effect of date or time of day on weight, providing the same results regardless of whether we used the tarsus length to correct the weight. Four sound features were constrained by male condition, of which the most important song characteristic of male condition was maximum trill quality. The generation of high vocal performance trill is not easy, because the generation of fast trill rate is restricted by bandwidth (Liu et al. 2017). Higher vocal performance produced by heavier males is also found in Swamp Sparrow (Melospiza georgiana) (Ballentine 2009). Studies of Nightingales suggest that older males are closer to the performance limit than younger males (Sprau et al. 2013). Male condition among Dusky Warblers was negatively correlated with maximum peak frequency of songs, the results being inconsistent with the relationship between tarsus length and peak frequency (Liu et al. 2017), and it was reasonable because previous studies have shown that weight is not affected by other body parameters (Liu 2016). Similar to results in this study, a relationship between weight and song pitch was also found in Silvereyes (Zosterops lateralis), Barn Swallows (Hirundo rustica), and even in non-songbirds (Galeotti et al. 1997; Hardouin et al. 2007; Potvin 2013). The correlation between the number of syllables and male condition of Dusky Warblers was not found in the Chiffchaff (Phylloscopus collybita), and it may be used to encode information about escalation battles of male Chiffchaff (Linhart et al. 2012).

Previous studies on Dusky Warblers have shown that males which possessed heavier weight and kept high sound amplitude during singing received more opportunities for extra-pair mating (Forstmeier 2002; Forstmeier et al. 2002). However, it remains unknown whether there is a relationship between male condition and song amplitude.

Many studies have shown that song characteristics cannot reflect weight, contrary to the results of this study (Cardoso et al. 2008; Lu et al. 2014; Linhart and Fuchs 2015). It is possible that the number of sound parameters is less than that of this study. In this study, 54 sound parameters were analyzed, including the extreme value of each sound parameter. Different studies have used different indicators to reflect body size in birds (Searcy 1979; Koivula et al. 1993; Jonart et al. 2007; Hall et al. 2013; Lu et al. 2014), as a result, outcomes may be inconsistent across studies.

\section{Conclusions}

In this study, we disclosed the relationship between the male condition and song features of the small songbird, Dusky Warbler, and that the most important song characteristic for body condition was the maximum trill quality, which suggested that the extreme song features were more constrained by male condition than mean sound characteristics. 
They may judge each other's male condition based on extreme of sound characteristics whether in mate selection or territorial competition. However, whether song characteristics can be used as reliable indicators of male condition, we will artificially change the sound characteristics related to condition and playback the song to resident males to observe whether males in the field show different responses.

\section{Additional file}

Additional file 1: Table S1. Descriptive statistics of sound parameters in Dusky Warblers.

\section{Acknowledgements}

We thank the Hebei Provincial Wildlife Protection of Forestry Department for permitting us to do our research. We thank Canchao Yang for his help with data analyses and our partners for their valuable help with fieldwork. We would like to thank Editage (www.editage.com) for English language editing and publication support.

\section{Authors' contributions}

$J H$ conceived and designed the experiments. JW and JL performed the experiment in the field. JW and JH processed and analyzed the data. JW wrote the manuscript. ZZ, HR, LG and JH made comments to the manuscript. All authors read and approved the final manuscript.

\section{Funding}

This study was funded by the Natural Science Foundation of Hebei Province (No. C2012204087) and the Natural Science Research Plan Project of Hebei University (No. 2014-299).

\section{Availability of data and materials}

The datasets used in the present study are available from the corresponding author on reasonable request.

\section{Ethics approval and consent to participate}

The experiments comply with the current laws of China. Experimental procedures were approved by the Hebei Provincial Wildlife Protection of Forestry Department.

\section{Consent for publication}

Not applicable.

\section{Competing interests}

The authors declare that they have no competing interests.

\section{Author details}

${ }^{1}$ College of Life Science, Hebei University, 54 East Road, Baoding 071000, China. ${ }^{2}$ Ministry of Education Key Laboratory for Ecology of Tropical Islands, College of Life Sciences, Hainan Normal University, Haikou 571158, China.

${ }^{3}$ College of Life Science, Hebei Agricultural University, Yu Ling Temple Street No. 289, Baoding 071000, China.

Received: 27 November 2018 Accepted: 13 May 2019 Published online: 20 May 2019

\section{References}

Ballentine B, Hyman J, Nowicki S. Vocal performance influences female response to male bird song: an experimental test. Behav Ecol. 2004;15:163-8.

Ballentine B. The ability to perform physically challenging songs predicts age and size in male swamp sparrows, Melospiza georgiana. Anim Behav. 2009;77:973-8.
Bertelli S, Tubaro PL. Body mass and habitat correlates of song structure in a primitive group of birds. Biol J Linn Soc. 2002;77:423-30.

Botero CA, Rossman RJ, Caro LM, Stenzler LM, Lovette IJ, De Kort SR, Vehrencamp SL. Syllable type consistency is related to age, social status and reproductive success in the tropical mockingbird. Anim Behav. 2009;77:701-6.

Brumm H. Song amplitude and body size in birds. Behav Ecol Sociobiol. 2009;63:1157-65

Byers BE. Extra pair paternity in chestnut-sided warblers is correlated with consistent vocal performance. Behav Ecol. 2007;18:130-6.

Byers BE, Akresh ME, King DI. Song and male quality in prairie warblers. Ethology. 2016;122:660-70.

Candolin U, Voigt HR. Correlation between male size and territory quality: consequence of male competition or predation susceptibility? Oikos. 2001;95:225-30.

Cardoso GC, Mamede AT, Atwell JW, Mota PG, Ketterson ED, Price TD. Song frequency does not reflect differences in body size among males in two oscine species. Ethology. 2008;114:1084-93.

Cardoso GC. Paradoxical calls: the opposite signaling role of sound frequency across bird species. Behav Ecol. 2012;23:237-41.

Catchpole CK, Slater PJB. Bird song: biological themes and variations. Cambridge: Cambridge University Press; 2008.

Davies NB, Halliday TR. Deep croaks and fighting assessment in toads Bufo bufo. Nature. 1978;274:683-5.

Draganoiu TI, Nagle L, Kreutzer M. Directional female preference for an exaggerated male trait in canary (Serinus canaria) song. Proc R Soc B. 2002;269:2525-31.

Forstmeier W, Kempenaers B, Meyer A, Leisler B. A novel song parameter correlates with extra-pair paternity and reflects male longevity. Proc $\mathrm{R}$ Soc $B$. 2002;269:1479-85.

Forstmeier W, Balsby T. Why mated dusky warblers sing so much: territory guarding and male quality announcement. Behaviour. 2002;139:89-111.

Forstmeier W. Individual reproductive strategies in the dusky warbler (Phylloscopus fuscatus): female and male perspectives. PhD Thesis. Germany: Max-Planck-Forschungsstelle für Ornithologie; 2002.

Galeotti P, Saino N, Sacchi R, Møller AP. Song correlates with social context, testosterone and body condition in male barn swallows. Anim Behav. 1997:53:678-700.

Gil D, Gahr M. The honesty of bird song: multiple constraints for multiple traits [review]. Trends Ecol Evol. 2002;17:133-41.

Handford P, Lougheed SC. Variation in duration and frequency characters in the song of the rufous-collared sparrow, Zonotrichia capensis, with respect to habitat, trill dialects and body size. Condor. 1991;93:644-58.

Hall ML, Kingma SA, Peters A. Male songbird indicates body size with lowpitched advertising songs. PLOS ONE. 2013;8:e56717.

Hardouin LA, Reby D, Bavoux C, Bruneleau G, Bretagnolle V. Communication of male quality in owl hoots. Am Nat. 2007;169:552-62.

Hughes M. Size assessment via a visual signal in snapping hrimp. Behav Ecol Sociobiol. 1996:38:51-7

Irwin DE, Thimgan MP, Irwin JH. Call divergence is correlated with geographic and genetic distance in greenish warblers (Phylloscopus trochiloides): a strong role for stochasticity in signal evolution? J Evol Biol. 2008:21:435-48.

Ivanitskii WV, Marova IM, Malykh IM. Between order and chaos: contrasting syntax in the advertising song of dusky (Phylloscopus fuscatus) and Radde's (Ph. schwarzi) warblers. J Ornithol. 2012;153:337-46.

Jonart LM, Hill GE, Badyaev AV. Fighting ability and motivation: determinants of dominance and contest strategies in females of a passerine bird. Anim Behav. 2007;74:1675-81.

Jones TM, Ward MP, Benson TJ, Brawn JD. Variation in nestling body condition and wing development predict cause-specific mortality in fledgling dickcissels. J Avian Biol. 2017:48:439-47.

Koivula K, Lahti K, Orell M, Rytkönen S. Prior residency as a key determinant of social dominance in the willow tit (Parus montanus). Behav Ecol Sociobiol. 1993;33:283-7

Kroodsma DE, Byers BE. The function(s) of bird song. Integr Comp Biol. 1991;31:318-28.

Labocha MK, Hayes JP. Morphometric indices of body condition in birds: a review. J Ornithol. 2012;153:1-22. 
Linhart P, Slabbekoorn H, Fuchs R. The communicative significance of song frequency and song length in territorial chiffchaffs. Behav Ecol. 2012;23:1338-47.

Linhart P, Fuchs R. Song pitch indicates body size and correlates with males' response to playback in a songbird. Anim Behav. 2015;103:91-8.

Liu JP. Song and body size of dusk warbler (Phylloscopus fuscatus) at Saihanba in Hebei. Master's Thesis. Baoding, China: Hebei Agricultural University; 2016. (in Chinese)

Liu JP, Zhang ZQ, Gu DH, Ma LK, Hou JH. Song characteristics analysis of the dusky warbler (Phylloscopus fuscatus) at Saihanba in Hebei. Chin J Zool. 2016;51:207-13 (in Chinese).

Liu JP, Ma LK, Zhang ZQ, Gu DH, Wang JJ, Li JJ, Gao LJ, Hou JJ. Maximum frequency of songs reflects body size among male dusky warbler Phylloscopus fuscatus (Passeriformes: Phylloscopidae). Ital J Zool. 2017;84:186-92.

Lu SF, Liu J, Xia CW. Lack of body size and beak length constraints on the frequency of Emberiza godlewskii's song. Chin J Zool. 2014;49:334-40 (in Chinese)

Martens J, Tietze DT, Eck S, Veith M. Radiation and species limits in the Asian Pallas's warbler complex (Phylloscopus proregulus sl). J Ornithol. 2004;145:206-22.

Martin JP, Doucet SM, Knox RC, Mennill DJ. Body size correlates negatively with the frequency of distress calls and songs of neotropical birds. J Field Ornithol. 2011;82:259-68.

Miyashita A, Kizaki H, Sekimizu K, Kaito C. No effect of body size on the frequency of calling and courtship song in the two-spotted cricket, Gryllus bimaculatus. PLOS ONE. 2016;11:e0146999.

Päckert M, Martens J, Eck S, Nazarenko AA, Valchuk OP, Petri B, Veith M. The great tit (Parus major) — a misclassified ring species. Biol J Linn Soc. 2005:86:153-74.
Patel R, Mulder RA, Cardoso GC. What makes vocalisation frequency an unreliable signal of body size in birds? A study on black swans. Ethology. 2010;116:554-63.

Potvin DA. Larger body size on islands affects silvereye Zosterops lateralis song and call frequency. J Avian Biol. 2013;44:221-5.

Price JJ, Christopher L. Use and characteristics of two singing modes in pine warblers. Wilson J Ornithol. 2013;125:552-61.

Robertson JGM. Male territoriality, fighting and assessment of fighting ability in the Australian frog Uperoleia rugosa. Anim Behav. 1986;34:763-72.

Searcy WA. Morphological correlates of dominance in captive male red winged blackbirds. Condor. 1979;81:417-20.

Searcy WA, Anderson RC, Nowicki S. Bird song as a signal of aggressive intent. Behav Ecol Sociobiol. 2006;60:234-41.

Sprau P, Roth T, Amrhein V, Naguib M. The predictive value of trill performance in a large repertoire songbird, the nightingale Luscinia megarhynchos. J Avian Biol. 2013;44:567-74.

Tubaro PL, Mahler B. Acoustic frequencies and body mass in New World doves. Condor. 1998;100:54-61.

Xiao H, Zhou ZX, Wang N, Zhang YY. Analyzing song characteristics of Yellowbellied Tits (Parus venustulus). Zool Res. 2008;29:277-84 (in Chinese).

Wagner WE. Fighting, assessment, and frequency alteration in Blanchard's cricket frog. Behav Ecol Sociobiol. 1989;25:429-36.

Wallschläger D. Correlation of song frequency and body weight in passerine birds. Experientia. 1980;36:412.

Zheng GM. Ornithology. Beijing: Beijing Normal University Press; 2011.
Ready to submit your research? Choose BMC and benefit from:

- fast, convenient online submission

- thorough peer review by experienced researchers in your field

- rapid publication on acceptance

- support for research data, including large and complex data types

- gold Open Access which fosters wider collaboration and increased citations

- maximum visibility for your research: over 100M website views per year

At BMC, research is always in progress.

Learn more biomedcentral.com/submissions 